\title{
RECENT BRACHIOPODS FROM THE SOUTHERN BRAZILIAN SHELF: PALAEONTOLOGICAL AND BIOGEOGRAPHICAL IMPLICATIONS
}

\author{
by MARCEllo G. Simões, MiChą KOWALEWSi, LUiz H. C. MELlo, \\ DAVID L. RODLAND and MONICA CARROLL
}

\begin{abstract}
Until recently, the rhynchonelliform (articulated) brachiopod fauna from the Brazilian continental shelf (western South Atlantic) was represented only by the endemic species Bouchardia rosea (Mawe), reported from coastal waters of the states of São Paulo and Rio de Janeiro. The present study, based on samples from coastal $(<30 \mathrm{~m})$, shelf, and continental slope waters (99-485 m), documents the South Atlantic brachiopod fauna and shows that this fauna is more widespread, diverse, and cosmopolitan than previously thought. Based on a total of 16,177 specimens, the following brachiopods have been identified: Bouchardia rosea (Family Bouchardiidae), Platidia anomioides (Family Platidiidae), Argyrotheca cf. cuneata (Family Megathyrididae), and Terebratulina sp. (Family Cancellothyrididae). In coastal settings, the fauna is overwhelmingly dominated by Bouchardia rosea. Rare juvenile $(<2 \mathrm{~mm})$ specimens of Argyrotheca cf. cuneata were also found at two shallow-water sites. In shelf settings (100-200 m), the fauna is more diverse and includes Bouchardia rosea, Terebratulina sp., Argyrotheca cf. cuneata, and Platidia anomioides. Notably, Bouchardia rosea was found in waters as deep as $485 \mathrm{~m}$, extending the known bathymetric range of this genus. Also, the record of this brachiopod in waters of the state of Paraná is the southernmost known occurrence of this species. The genera Platidia and Terebratulina are documented here for the first time for the western South Atlantic. The Brazilian brachiopod fauna shares similarities with those from the Atlantic and Indian shelves of southern Africa, and from the Antarctic, Caribbean and Mediterranean waters. The present-day brachiopods of the western South Atlantic are much more cosmopolitan than previously thought and their Cenozoic palaeobiogeographic history has to be reconsidered from that perspective.
\end{abstract}

KEY WORDS: Terebratulida, Recent, South-East Brazilian Bight.

Although Recent brachiopods have been extensively studied in many regions (e.g. Williams et al. 1965, 1997; Rudwick 1970; Dutro and Boardman 1981; MacKinnon et al. 1990; James et al. 1992; Copper and Jin 1996; Savazzi 1999; Peck 2001), it was demonstrated only recently that this group is abundant and widespread on subtropical shelves of eastern South America (Kowalewski et al. 2002). Previous research has focused on the coasts and shelves of New Zealand and Australia (e.g. Richardson 1981a, 1987, 1994; Lee 1991), the Mediterranean Sea (Logan 1979; Brunton 1988), Caribbean Sea (Cooper 1977), the coasts of South Africa (Hiller 1990, 1994), Japan (Hatai 1940), California (Buening and Spero 1996; Pennington et al. 1999), the Antarctic shelf (Foster 1974), and many other regions of modern oceans (Muir-Wood 1959; Cooper 1973a; Zezina 1981a; Curry 1982; Tunnicliffe and Wilson 1988; Laurin 1997). Although these studies provide an impressive geographic coverage, there still exist large regions of the world, most notably perhaps, the eastern South Atlantic Ocean, that have been largely neglected by brachiopod workers. As shown here, the Brazilian waters host an important brachiopod fauna that is as abundant and easily accessible as those more renowned associations from other regions of the world.

According to previous studies (see Davidson, 1887, p. 145, for a possible exception), the articulated brachiopods (currently classified as Rhynchonelliformea; see Williams et al. 1996, 1997) from the Brazilian continental shelf (the western South Atlantic) are represented only by the endemic species Bouchardia rosea (Mawe), a small brachiopod with a calcitic shell that reaches up to $25 \mathrm{~mm}$ in length. The species is a patchily distributed but locally abundant element of present-day Brazilian marine benthic 
communities that inhabit the shores of the states of São Paulo, Rio de Janeiro, and Espírito Santo (Tommasi 1967, 1970a, $b$; Nonato and Petti 1996; Nonato 1999). In addition, the inarticulated brachiopod Discinisca has been reported a few times from the coast of São Paulo (Nonato and Petti 1996; Nonato 1999).

Tommasi (1970a), in the most comprehensive paper published to date and the only one that deals specifically with living Brazilian brachiopods, recorded hundreds of specimens of $B$. rosea from a number of stations along the coast of the state of Rio de Janeiro. Since the publication of Tommasi's work only one paper, by Manceñido and Griffin (1988), has added to our knowledge of the distribution and possible importance of the Brazilian brachiopod fauna. The paper has mostly confirmed and reviewed previous records, without adding any new brachiopod species. Recently, Nonato and Petti (1996) and Nonato (1999) recorded the presence of $B$. rosea along the northern coast of the state São Paulo, confirming previous observations on the biogeographic distribution of this species.

In contrast to the previous studies, our report is based on very extensive sampling of the benthic fauna from the coast and shelf of the southern Brazil and shows that the South Atlantic brachiopod fauna from Brazil is more widespread, diverse and cosmopolitan than previously thought. This study provides the first taxonomic documentation of the rhynchonelliform brachiopods from the Brazilian coast of the South Atlantic Ocean and focuses primarily on the biogeography and taxonomy of brachiopods. Quantitative aspects of the overall distribution of brachiopods in terms of substrate, bathymetry and ocean water masses are discussed in detail elsewhere (Kowalewski et al. 2002).

\section{MATERIAL AND METHODS}

In 1997 and 1998, numerous samples of benthic macrofauna were collected off the coast of the states of Rio de Janeiro, São Paulo and Paraná (latitudinal range: $23^{\circ} 45^{\prime} \mathrm{S}-29^{\circ} 59^{\prime} \mathrm{S}$ ), Brazil (Text-fig. 1). All samples were collected as a part of a five year (1995-2000) oceanographic project (REVIZEE Score Sul: Programa de Avaliação do Potencial Sustentável dos Recursos Vivos na Zona Econômica Exclusiva; see also http://www.cnpq.br/programas/revizee.htm). In the scope of this project, a total of 195 samples of surface sediments from 101 sites were taken by Van Veen grabs $(n=93)$, box cores $(n=65)$, and dredges $(n=37)$. During the screening of the material, all macrobenthic invertebrates $(>0 \cdot 1 \mathrm{~mm})$ were identified to class level, counted, and sorted by the REVIZEE project members. In 1999, the REVIZEE brachiopod collection was donated to the Palaeontological Collection of the Department of Zoology, Institute of Biosciences, São Paulo State University, at Botucatu Campus, São Paulo State, where the specimens are currently housed. In addition, we collected brachiopods from 29 sites in shallow-water settings $(>30 \mathrm{~m})$ from the coast of Ubatuba (São Paulo) and Ilha Grande (Rio de Janeiro) (Text-fig. 1). A combined total of 16,177 brachiopods from the Brazilian waters (12,451 from REVIZEE) were obtained for this study.

The brachiopods were counted and identified to species level. However, owing to their small size and extremely fragile shells, the specimens studied presented difficulties not only during the initial sampling, but also during the subsequent laboratory analyses (see also Foster 1989). Nevertheless, anatomical dissections were made successfully for several specimens without damaging the shells and their soft parts were photographed using a Zeiss stereomicroscope with a digital camera. After that, the soft parts of some specimens were removed by dissolving tissues for 24 hours in a 10 per cent solution of $\mathrm{H}_{2} \mathrm{O}_{2}$. The remaining tissues were removed with care using small probes under the stereomicroscope. The internal and external dimensions of the shells were measured using digital images acquired with the Scanning Electron Microscope (SEM) facility of the Institute of Geosciences, University of São Paulo and the Zeiss stereomicroscope digital camera. The density of puncta was estimated as in Foster (1974), but see also Foster (1989) for the discussion of the taxonomic value of this character.

\section{PRESENT-DAY BRACHIOPOD FAUNA FROM THE SOUTHERN BRAZILIAN SHELF}

\section{Faunal composition}

A detailed screening of the material revealed that the Brazilian articulated brachiopod fauna includes at least four genera. They include members of the families Cancellothyrididae (Terebratulina sp.), 


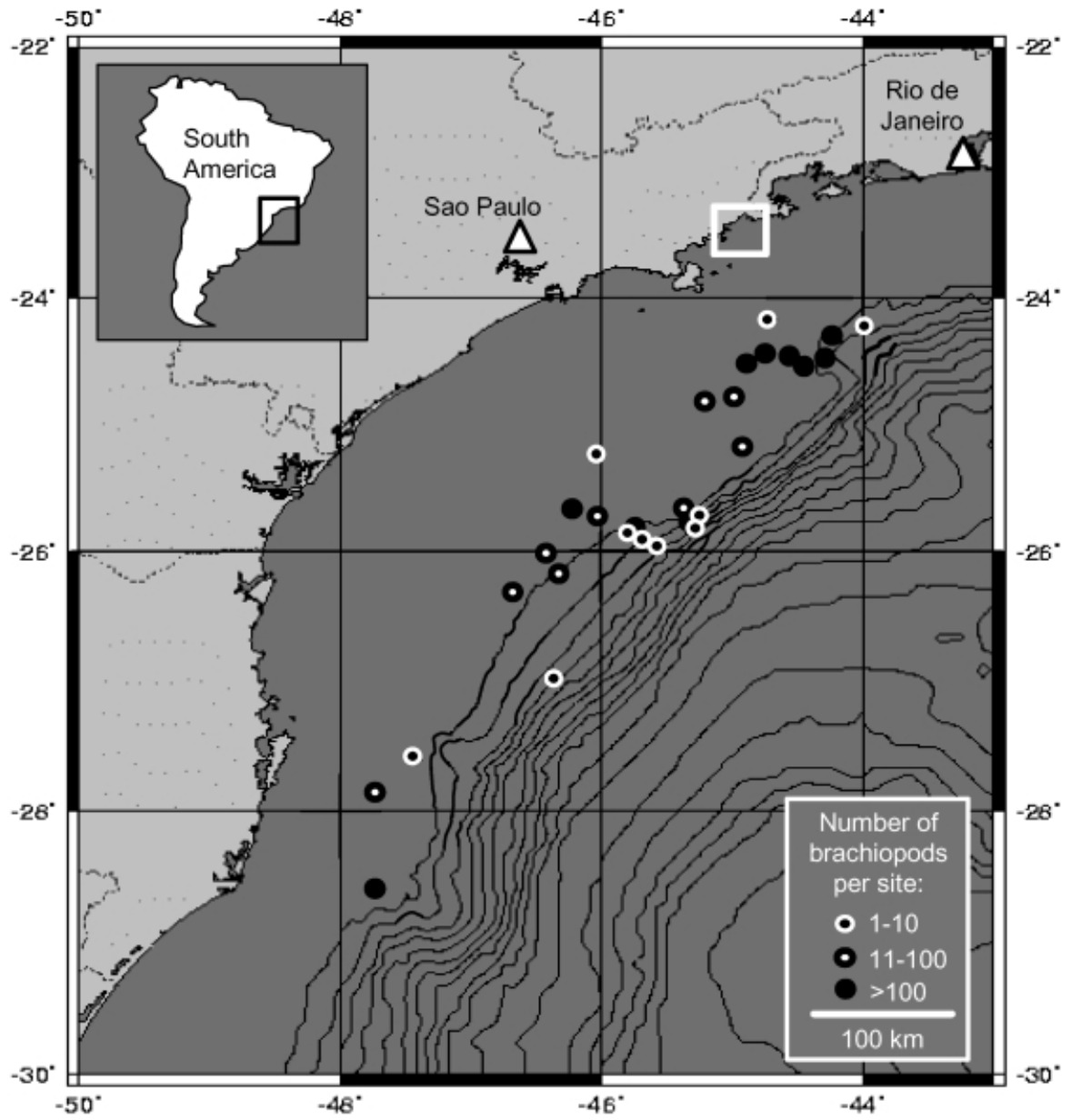

TEXT-FIG. 1. Study area and sampling localities. A white rectangle indicates the area of coastal sampling (Ubatuba Bay area). Dots indicate geographic position of sites sampled that yielded articulated brachiopods on the outer shelf during the REVIZEE Score Sul Benthos project on the South-East Brazilian Bight. The figure was generated using the

Generic Mapping Tools available at http://www.aquarius.geomar.de/omc/make_map.html.

Megathyrididae (Argyrotheca cf. cuneata), Platidiidae (Platidia anomioides), and Bouchardiidae (Bouchardia rosea). This is the first record of the genera Terebratulina and Platidia in the tropical and subtropical waters of the western South Atlantic Ocean. This discovery stands in sharp contrast with the widely accepted view (e.g. Tommasi 1970a; Nonato and Petti 1996; Nonato 1999) that only one endemic species (B. rosea), confined to a restricted number of shallow water sites, is present in Brazilian waters. Also, the abundance of brachiopods, especially on the outer shelf, undermines the widely accepted generalization that articulated brachiopods are rare in open-water habitats at low latitudes (for quantitative ecological data and their implications, see Kowalewski et al. 2002).

Although this fauna is unexpectedly abundant, its diversity is low, particularly if compared with other brachiopod faunas from the South Atlantic and adjacent regions (Cooper 1973b, 1977, 1982; Foster 1974; Hiller 1994). For example, the southern African fauna, revised by Hiller (1990, 1994), includes members of 13 families of articulated brachiopods. On the other hand, the Brazilian fauna is overwhelmingly dominated by B. rosea, whereas the three other species (Terebratulina sp., Platidia anomioides, and 


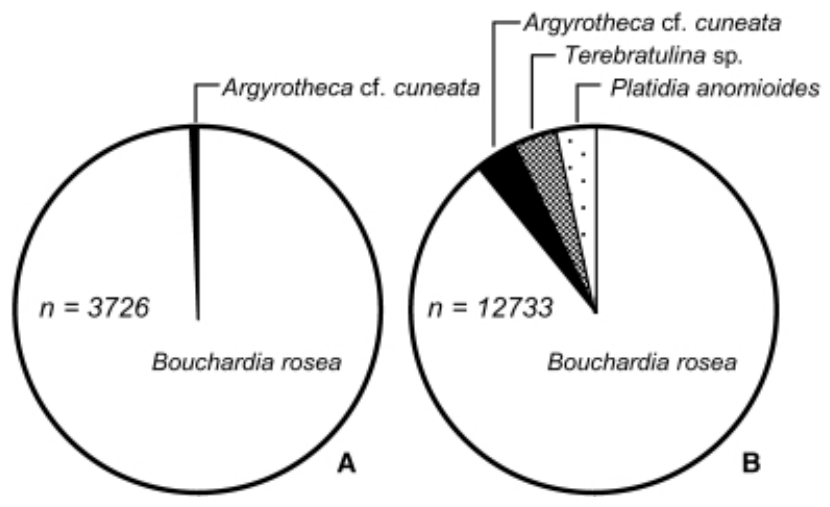

TEXT-FIG. 2. Relative abundance of brachiopod species in the study area. Italicized numbers indicate total numbers of specimens examined. A, faunal composition of brachiopods found in coastal samples. B, faunal composition of brachiopods found in shelf samples.

Argyrotheca cf. cuneata) occur in notable quantities on the outer shelf only and are virtually absent in the coastal zone (Text-fig. 2).

\section{Substrate preferences}

In all occurrences analyzed the brachiopods are restricted to carbonate substrates, represented by coarse biogenic sediments with the bulk sediment content of $\mathrm{CaCO}_{3}$ exceeding 40 per cent $B$. rosea inhabits substrate with carbonates ranging from 40-70 per cent and the other three species occur in substrates with carbonates exceeding 70 per cent. Most probably, the coarse biocarbonate sediments are preferentially colonized because they provide a hard substrate for attachment (Fürsich and Hurst 1974). It is noteworthy that Terebratulina sp., Argyrotheca cf. cuneata, and P. anomioides, when recovered alive, were often attached to sedimentary grains or shells of other invertebrates (e.g. bivalve molluscs) (Text-fig. 3). In contrast, $B$. rosea is probably a free-living organism with a pedicle that may function as a free, active organ suitable for ratcheting action (see also Richardson 1981b, 1997b, and below).

\section{Bathymetric distribution}

The brachiopods are most common in the depth range between 100 and $250 \mathrm{~m}$ (Text-fig. 4). Only a few specimens were found in very shallow waters $(<30 \mathrm{~m})$ and in waters as deep as $450 \mathrm{~m}$. This pattern is very similar to that shown by the southern African fauna (see Hiller 1994). Based on Van Veen grab and box core samples, the estimated shell abundance varies from 1 to over 50,000 specimens per cubic metre of surficial sediment. All species display a patchy distribution. Three distinct brachiopod associations are present: (1) B. rosea-dominated fauna; (2) Terebratulina-Argyrotheca fauna; and (3) Platidia-dominated fauna. In shallow-water settings $(<30 \mathrm{~m})$, the fauna is overwhelmingly dominated by $B$. rosea (see Text-fig. 2). In shelf settings $(<99-250 \mathrm{~m})$, the fauna is more diverse and includes in order of abundance B. rosea, Terebratulina sp., P. anomioides, and Argyrotheca cf. cuneata. The Bouchardia-dominated fauna and Terebratulina-Argyrotheca faunas are common at depths ranging from $100-200 \mathrm{~m}$. The Platidia-dominated fauna occurs in waters of 160-260 m.

The observed bathymetric pattern is very similar to that shown by the brachiopod fauna of southern Africa (see Hiller 1994) and the western South Atlantic waters of Argentina (Roux and Bremec 1996). For example, on the Argentinian continental shelf (sampled depth range: 20-192 m), brachiopod species (Liothyrella uva uva, Magellania venosa, Terebratella dorsata) are confined to the depth range of 55-189 m (Roux and Bremec 1996). 


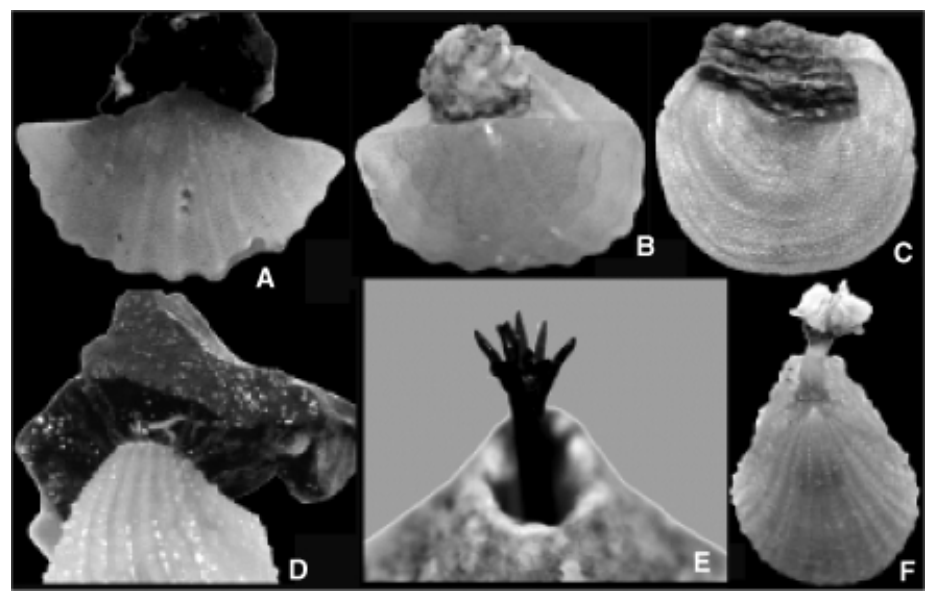

TEXT-FIG. 3. Brachiopods attached to various substrate particles. A, Argyrotheca cf. cuneata; DZP-15885; $\times 11$. B, Argyrotheca cf. cuneata; DZP-15886; ×7.7. C, Platidia anomioides; DZP-16295; $\times 10$. D, close-up of the Terebratulina sp. shell attached to a clastic grain; DZP-15395; $\times 7 \cdot 6$. E, the pedicle of inert type of Bouchardia rosea, showing the rootlets; DZP-4004; ×11. F, Terebratulina sp.; DZP-15396; $\times 5$.

The patchy distribution revealed in our samples is a common phenomenon among all types of brachiopods (Lee 1991; Kowalewski 1996). It may relate to abiotic factors, such as substrate preferences (see above), or other biotic (e.g. dispersal patterns) or physical factors (e.g. currents) that cannot be evaluated on the basis of available information.

Our data extend the known bathymetric range of some species. B. rosea, for example, was found in waters as deep as $485 \mathrm{~m}$. Until now, the bathymetric distribution of $B$. rosea was restricted to shallowerwater settings (less than $150 \mathrm{~m}$ ) (Tommasi 1970a; Manceñido and Griffin 1988), with the maximum abundance around 18-26 m (Tommasi 1970a). The presence of populations at depths down to $485 \mathrm{~m}$, indicates that $B$. rosea is able to colonize deep-water habitats of the continental slope. This observation, also noted for other articulated brachiopods such as Macandrevia americana, illustrates the complicated nature of brachiopod distribution and dispersal patterns (see Zezina 1981b, 1987; Foster 1989).

$P$. anomioides is a species known to inhabit abyssal areas that are located away from continental shelves and slopes, often at depths exceeding $2000 \mathrm{~m}$ (Foster 1989). P. anomioides was recorded on the Louisville Ridge (South Pacific Ocean) from 531 to $659 \mathrm{~m}$ (Foster 1989), on the Pacific Antarctic Ridge at $73 \mathrm{~m}$ (Foster 1974), and in the south coastal zone of southern Africa from 50 to $200 \mathrm{~m}$ (Hiller 1994). The data for P. marionensis (see Cooper 1981a) from the Southern Indian Ocean (a junior synonym of P. anomioides; see Foster 1989) indicate that the species has a very patchy distribution, with shallow and deep-water occurrences ranging from 90 to $570 \mathrm{~m}$ and 1350 to $1440 \mathrm{~m}$, respectively (Cooper 1981a). Thus, the studied populations of $P$. anomioides are within the known bathymetric range of the species.

The available data for Terebratulina fit the known bathymetric distribution of this genus. In southern African waters Terebratulina displays a wide bathymetric range from shallow waters $(50 \mathrm{~m})$ down to $800 \mathrm{~m}$ (Hiller 1994). Our occurrences are restricted to waters from 99 to $417 \mathrm{~m}$. This restriction may partly reflect the bathymetric range of samples. For example, along the Pacific coast of South America (south-west of Valparaiso and north-west of Constitucion, Chile), species of Terebratulina are recorded from waters as deep as 780-925 m (Cooper 1982) and around Antarctica the genus is found at depths of 1098-2342 m (Foster 1974). Finally, it should be noted that species with wide bathymetric distributions, such as B. rosea and Terebratulina sp., are also the species with widest latitudinal distribution in the study area.

\section{Biogeography and affinities of the fauna}

Tracing the origins of the present fauna is very difficult because of the scarcity of information concerning the Cretaceous and Cenozoic fossil record of brachiopods in the region. The available data give us only a 


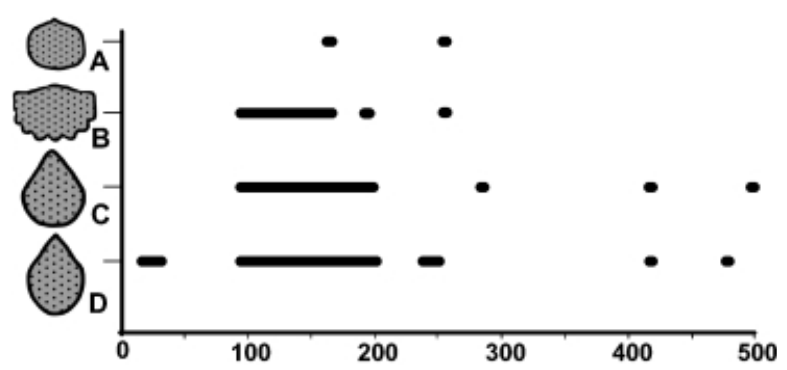

TEXT-FIG. 4. Bathymetric distribution of brachiopods on South-East Brazilian Bight. A, Pladitia anomioides. B, Argyrotheca cf. cuneata. C, Terebratulina sp. D, Bouchardia rosea.

very fragmentary picture of the biogeographic history of present-day Brazilian brachiopods. As observed by Foster (1974), the fossil record and the present-day distribution of brachiopods in the Southern Hemisphere suggest that the waters surrounding southern continents shared more faunal elements in the past than they do today. Antarctica and South America, for example, shared a number of taxa in the Cenozoic that are either extinct or occur only in South America today. According to Foster (1974), South America and Antarctica are the only southern continents whose faunas and geology suggest close connections in the Cenozoic. As discussed below, our data support this view only in part.

Based on current taxonomic information and the fossil record, the living brachiopods from the Brazilian waters seem to include two main components. The first includes the endemic form (B. rosea) that belongs to a genus with a long fossil record, extending back to the Cretaceous rocks of the southern continents. The second component includes species that are very widely distributed (for example, $P$. anomioides is almost world-wide in distribution throughout the Cenozoic) and/or belong to highly cosmopolitan genera (Argyrotheca, Platidia, and Terebratulina). The members of these genera are common today in many regions, including the Red Sea, the Mediterranean, Gulf of Mexico, Caribbean Sea, Mozambique Channel, South Africa, Argentina, Antarctica, and Australia (Cooper 1973b, 1977, 1979, 1981b; Foster 1974, 1989; Logan 1979, 1983; Zezina 1987; Brunton 1988; Hiller 1994; Richardson 1997a). They are also frequently found in the Cenozoic fossil record of Central America, south-eastern United States, and Europe (Cooper 1979; Richardson 1997a).

When compared to other areas, the Brazilian brachiopod fauna shows the greatest similarities with other Southern Hemisphere faunas, such as those from the Antarctic and Subantarctic (Foster 1974) and southern Africa (Hiller 1994). Argyrotheca sp., P. anomioides, and Terebratulina sp. are, for example, reported from the Atlantic and Indian shelves of southern Africa (see Hiller 1994). Also, Argyrotheca cf. cuneata is very similar to Argyrotheca sp. described by Hiller (1994), who also noted its similarities with A. cuneata. Thus, the present fauna consists of older endemic elements (Bouchardia) and newer (probably Cenozoic) immigrant forms, such as Argyrotheca, Platidia, and Terebratulina. However, it should be noted that Argyrotheca is also one of the most common brachiopods in Caribbean seas today (Cooper 1977) and Terebratulina is arguably the most common living articulated brachiopod (Foster 1974; Cooper 1981b).

The Brazilian brachiopod fauna is distinct from the Argentinian fauna, which is more diverse and dominated by species of the genera Liothyrella, Magellania, and Terebratella (Cooper 1973b; Roux and Bremec 1996). According to the faunal list provided by Cooper (1973b), the only unique genus shared in common by the Brazilian and Argentinian fauna is Platidia. Cooper (1973b), based on the occurrence of Platidia ( $P$. davidsoni) in Argentinian waters, suggested the presence of Mediterranean elements in the western South Atlantic. The differences between these two faunas may be, in part, related to abiotic factors. The Argentinian genera Terebratella, Liothyrella, and Magellania are found in cold waters (as cold as $3.8^{\circ} \mathrm{C}$ ) on various siliciclastic substrates (from mud to gravel) (Roux and Bremec 1996). In contrast, the Brazilian fauna inhabits much warmer waters $\left(13-20^{\circ} \mathrm{C}\right)$ and occurs on substrates with a carbonate content ranging from $40-70$ per cent. 
Even considering the complexity of vicariance biogeography driven by long-term processes of plate tectonics (i.e. break-up of Gondwana) and the multifaceted biogeographic history of terebratulide brachiopods (Richardson 1997a), the geographic origin of the Brazilian fauna remains puzzling. The absence of typical Southern Hemisphere representatives, and the occurrence of Mediterranean and West Indies elements in the fauna studied confirms the view that 'the real picture of brachiopod distribution and dispersal may be a bit more complicated than the traditional one' (Foster 1989, p. 269, but see also Dawson 1990). Finally, given the surprising ocean-current dispersal capabilities of some articulates documented by Curry and Endo (1991), the three cosmopolitan forms may have migrated with ocean currents from other, even geographically remote, regions where they are present.

It should be noted that the brachiopod fauna studied was collected from the 'Paulista' Marine Zoogeographic Province, which extends between the States of Espírito Santo and Rio Grande do Sul, being limited north and south by the $23^{\circ} \mathrm{C}$ isotherm (Palacio 1982). The biogeography of the brachiopod fauna is consistent with the biogeographic pattern commonly observed in this province for other groups of organisms: the mixed occurrence of both endemic organisms and immigrant elements.

\section{SYSTEMATIC PALAEONTOLOGY}

Repository. Figured material is housed in the Palaeontological Collection of the Department of Zoology, São Paulo State University, Botucatu, São Paulo, Brazil with the specimen-number prefix DZP.

Phylum BRACHIOPODA Duméril, 1806

Subphylum RHYNCHONELLIFORMEA Williams et al., 1997

Class RHYNCHONELLATA Williams et al., 1997

Order TEREBRATULIDA Waagen, 1883

Suborder TEREBRATULIDINA Waagen, 1983

Superfamily CANCELLOTHYROIDEA Thomson, 1926

Family CANCELLOTHYRIDIDAE Thomson, 1926

Genus TEREBRATULINA d'Orbigny, 1847

\section{Terebratulina sp.}

Text-figure $5 \mathrm{~A}-\mathrm{E}$

2000 Eucalathis sp. Simões and Kowalewski, p. 80.

2000 Eucalathis sp. Simões et al. p. 14.

Material. A total of 486 specimens (DZP-15,391-15,877) represented primarily by complete articulated shells.

Description. Small (maximum length $10.0 \mathrm{~mm}$, maximum width $8.6 \mathrm{~mm}$ ), subtriangular shell, with strong posterior costellation and anterior fasciculation. Posterolateral margins straight, forming apical angle of 67 degrees. Lateral commissure nearly straight; anterior commissure rectimarginate to broadly unplicate. Shell surface exterior multicostellate, with seven or eight more prominent beaded costellae. Costellae width more or less constant from the umbo to the anterior margin.

Ventral valve exterior moderately convex in lateral profile, flattening anteriorly, with wide shallow sulcus. Foramen wide and rounded, bounded by small disjunct deltidial plates. Dorsal valve exterior moderately convex in lateral profile; umbo smooth. Median fold poorly defined.

Ventral valve interior with short pedicle collar, two well-developed teeth, lacking dental plates. Dorsal valve interior with prominent inner socket ridges and small, semicircular ridged cardinal process. Loop wide, supported by stout crura fused in its anterior portion, forming a ring-like structure with a ventrally directed median fold.

Discussion. Following Foster (1974), we do not give a new name or assign our specimens to a known species. This is for the following reasons: (1) Terebratulina has more species than any other living articulated brachiopod genus; (2) the variation within and differences between the common Northern 
Hemisphere species of Terebratulina are poorly known (Foster 1974); and (3) the taxonomic differences between living and fossil representatives of genus Terebratulina are difficult to recognise in practice (Endo et al. 1995).

According to Cooper (1981a), the species assigned to Eucalathis tend to strongly resemble juvenile Terebratulina. In fact, the Brazilian material closely resembles various species of Eucalathis. For example, the outline, ornamentation and size of Terebratulina sp. is similar to that of Eucalathis costellata

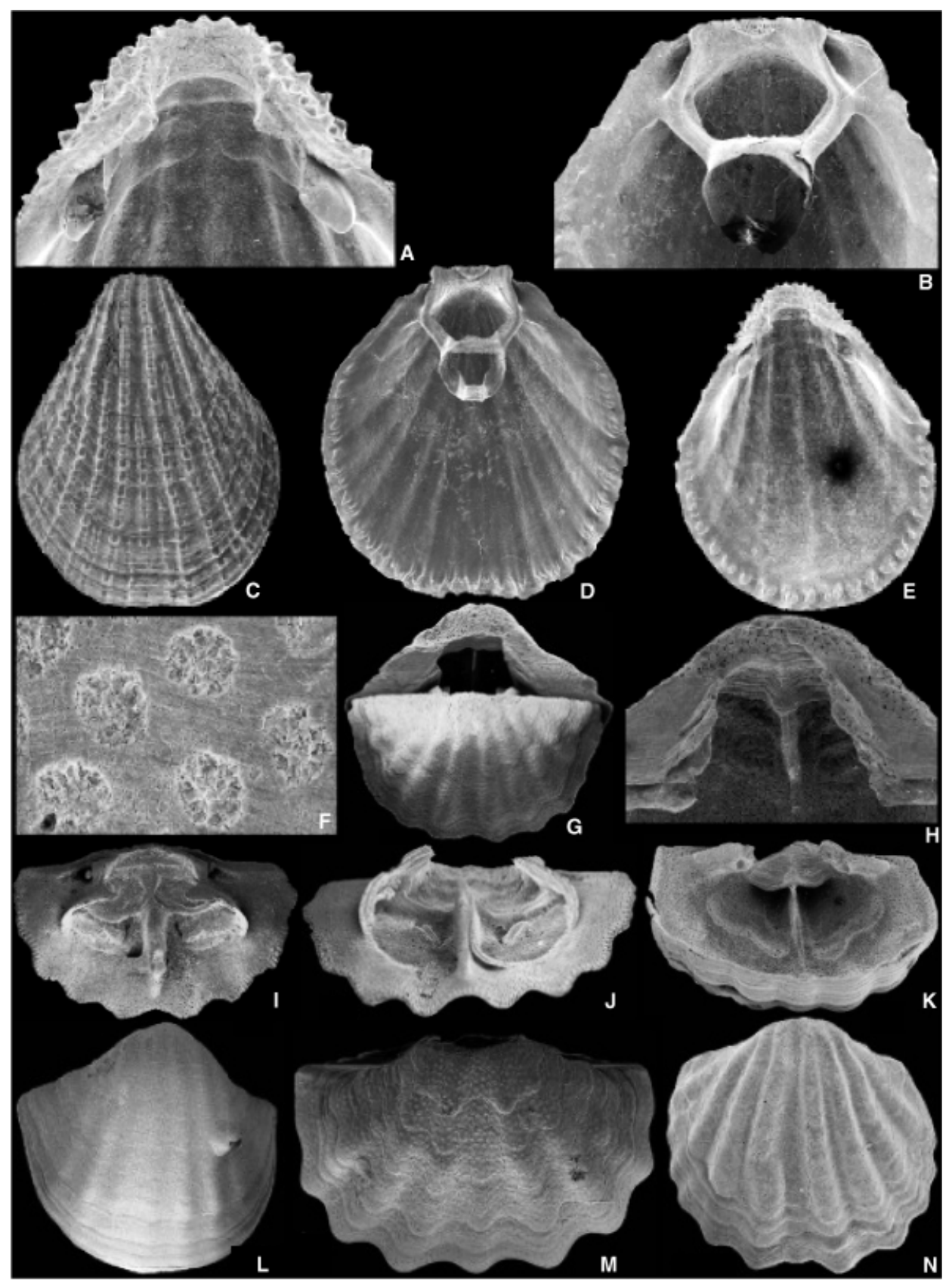


from the southern Indian Ocean (Cooper 1981a). However, the brachidium forming a ring-like loop observed in the Brazilian specimens (Text-fig. 5B, D) differs notably from the chlidonophorid loop (see Muir-Wood et al. 1965) that characterizes Eucalathis.

Fischer and Oehlert (1892) were the first authors to report Terebratulina from South America (Cape Horn). Blochmann (1908) and Eichler (1911) questioned this occurrence, but Foster (1974) found specimens of Terebratulina sp. in material from the Magellan Sound (Subantarctic Region). According to Foster (1974), the subantarctic shells of Terebratulina sp. resemble the North Atlantic species Terebratulina retusa in their spiculation. However, the Terebratulina sp. studied differs from T. retusa by their triangular outline, and more granular shell surface. It is noteworthy that Foster (1974) kept the Subantarctic species of Terebratulina as unidentified, but on the map of the geographic distribution of the cancellothyrid brachiopods in the Antarctic and Subantarctic regions they were questionably assigned to Terebratulina crossei (Foster 1974, p. 29, fig. 10). Unfortunately, Foster's specimens were not illustrated, but specimens of $T$. crossei described and figured by Cooper (1982) differ notably from the Terebratulina sp. examined. The outline of $T$. crossei is nearly circular, and the shell surface is ornamented by fine costellae. The same is also true of $T$. retusa emarginata and $T$. septentrionalis, described and/or figured by Cooper $(1981 b)$. Also, the more triangular outline and the shell surface with well-marked costellation distinguish the Brazilian Terebratulina sp. from T. kiiensis, and Terebratulina sp. in Cooper (1982). A triangular outline and strong radial ornamentation is also present in Terebratulina sp. from South African waters (Hiller 1986, p. 120, fig. 10). Unfortunately, the loop is not preserved in any of the Hiller's specimens.

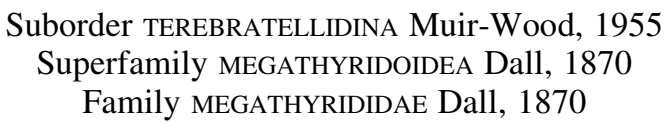

Genus ARGYROTHECA Dall, 1900

Argyrotheca cf. cuneata (Risso, 1826)

Text-figure $5 \mathrm{~F}-\mathrm{N}$

Material. A total of 409 specimens (DZP-15,878-16,287) represented primarily by complete articulated shells.

Description. Small (maximum length $5 \mathrm{~mm}$, maximum width $5.8 \mathrm{~mm}$ ), biconvex, amber coloured shell, with highly variable outline (but usually with the longest lateral dimension), ranging from globose to transversely subrectangular, with the maximum width at the hinge margin. External surface of both valves covered with 7-8 flat, rounded ribs. Occasionally, a wider median groove with one short, intercalated rib may be present.

Ventral valve more convex than the dorsal one. The beak is short, smooth, incurved. Foramen triangular, hypothyrid, restricted by two narrow disjunct deltidial plates. Ventral valve exterior moderately convex in lateral

TEXT-FIG. 5. A, Terebratulina sp., close-up of the posterior end of the ventral valve; DZP-15393; $\times 19 \cdot 2$. B, close-up of the 'ring-like' loop of the same specimen; $\times 19 \cdot 2$. C, ventral view of specimen DZP-15394; $\times 6.3$, showing ornamentation. D, dorsal valve interior view; DZP-15392; $\times 10$. E, general view of the ventral valve interior; $\times 6 \cdot 4$. All illustrated specimens of Terebratulina sp. from Station 6665 collected during a REVIZEE Cruise on January 1, 1998. F, punctae of Argyrotheca cf. cuneata; DZP-15883; $\times 232$. G, Argyrotheca cf. cuneata, dorsal view, showing the foramen; DZP-15882; $\times 12 \cdot 3$. $\mathrm{H}$, the same specimen, showing detail of foramen and deltidial plates; $\times 21$. I-J, dorsal valve interior of Argyrotheca $\mathrm{cf}$. cuneata; DZP-15879. I, note the high median septum; $\times 17 \cdot 2$. J, note the brachidium forming a simple loop, and the absence of tubercules on the internal side of the anterior margin of Argyrotheca cf. cuneata shell; $\times 20 \cdot 7 . \mathrm{K}$, ventral valve interior of Argyrotheca $\mathrm{cf}$. cuneata, showing the collar supported by the median septum; DZP-15884; $\times 14 \cdot 5$. L, ventral view of Argyrotheca $\mathrm{cf}$. cuneata shell with rounded outline; DZP-15883; $\times 12 \cdot 2$. M, ventral view of Argyrotheca cf. cuneata shell; DZP-15880; $\times 17 \cdot 6$. N, external surface of Argyrotheca cf. cuneata shell, showing flat, rounded ribs; DZP-15881; $\times 17 \cdot 6$. All illustrated specimens of Argyrotheca cf. cuneata from Station 6676, REVIZEE Cruise on January 12, 1998. 
profile, flattening anteriorly, with wide shallow sulcus. Dorsal valve exterior moderately convex in lateral profile; umbo smooth. Median fold poorly defined.

Ventral valve interior with a well-developed pedicle collar, supported by the median septum, which may extend anteriorly to the middle of the shell. Adductor muscle scars deeply insert either side of median septum. Teeth wide and triangular. The internal side of the anterior margin of the ventral valve without tubercules. Dorsal valve interior with high median septum reaching maximum height near the anterior margin. The brachidium forms a simple loop, with two descending branches, anteriorly attached to the end of median septum. Sockets short, conical. Lophophore of schizolophous type. Internal side of the anterior margin of the dorsal valve without tubercules.

Discussion. Externally Argyrotheca closely resembles Megathyris, but the presence of one median dorsal septum in the former and the occurrence of three in the latter separate these genera. Thus, the presence of one median dorsal septum in the shells analysed justifies the assignment of the Brazilian material to the genus Argyrotheca. Also, all specimens examined internally display a schizolophe lophophore (as expected for Argyrotheca) and not a ptycholophe lophophore (as would be the case for Megathyris).

As in other megathyridid brachiopods (e.g. Popiel-Barczyk and Barczyk 1987, 1990; Bitner 1990, 1993), the specimens investigated strongly support opinions concerning a wide intraspecific variation in shell outline and ornamentation of the species assigned to Argyrotheca and Megathyris.

The specimens of Argyrotheca cf. cuneata examined vary in shape from broadly transverse forms with a long straight hinge line (alate form) to more globose forms (Text-fig. 5G, L-N). These variations appear to be independent of the size of specimens and, thus, are not necessarily ontogenetic. In fact, as noted by Thayer (1977), specimens of Recent Terebratalia transversa exhibit alate and globose morphotypes in the same population. Globose individuals grow faster in length than in width, while alate individuals grow faster in width than in length (Thayer 1977). In the material examined the different morphotypes are observed among specimens from within the same sites. Thus, this morphological variability does not appear to be dependent on specific environmental conditions but rather, as suggested by Thayer (1977), may be genetically controlled.

The Brazilian shells lie within the range of morphological variation of A. cuneata (e.g. Bitner 1990, 1993), and their ornamentation is similar to that of this species. Also, the shells examined are externally similar to Argyrotheca sp. from South Africa, described by Hiller (1994). As is the case for the Brazilian shells, the single southern African specimen resembles A. cuneata, especially in its ornamentation (Hiller 1994), but the ventral interarea is not as long as in the Brazilian specimens. Both occurrences may represent $A$. cuneata. This is particularly likely considering the notable morphological intra-population variability demonstrated for this genus here and elsewhere. Yet it should be noted that Davidson (1887) referred to Cistella (=Argyrotheca) barrettiana some specimens dredged from $128 \mathrm{~m}$ off Rio de Janeiro. Davidson (1887) noted the similarity of these specimens to Argyrotheca cuneata. The main difference is that the specimens attributed to Argyrotheca barrettiana are larger and possess a greater number of ribs (Davidson 1887, p. 146). Given the intra-population variations in size, shape and ornamentation, Davidson's specimens from Rio de Janeiro must be compared with the specimens herein described as Argyrotheca cf. cuneata.

Superfamily PLATIDIOIDEA Thomson, 1927

Family PLATIDIIDAE Thomson, 1927

Genus PLATIDIA Costa, 1852

Platidia anomioides (Scacchi and Philippi, 1844)

Text-figure 6

2000 Amphithyris sp. Simões and Kowalewski, p. 80.

2000 Amphithyris sp. Simões et al. p. 14.

Material. A total of 446 specimens (DZP-16,288-16,734) represented primarily by complete articulated shells. 


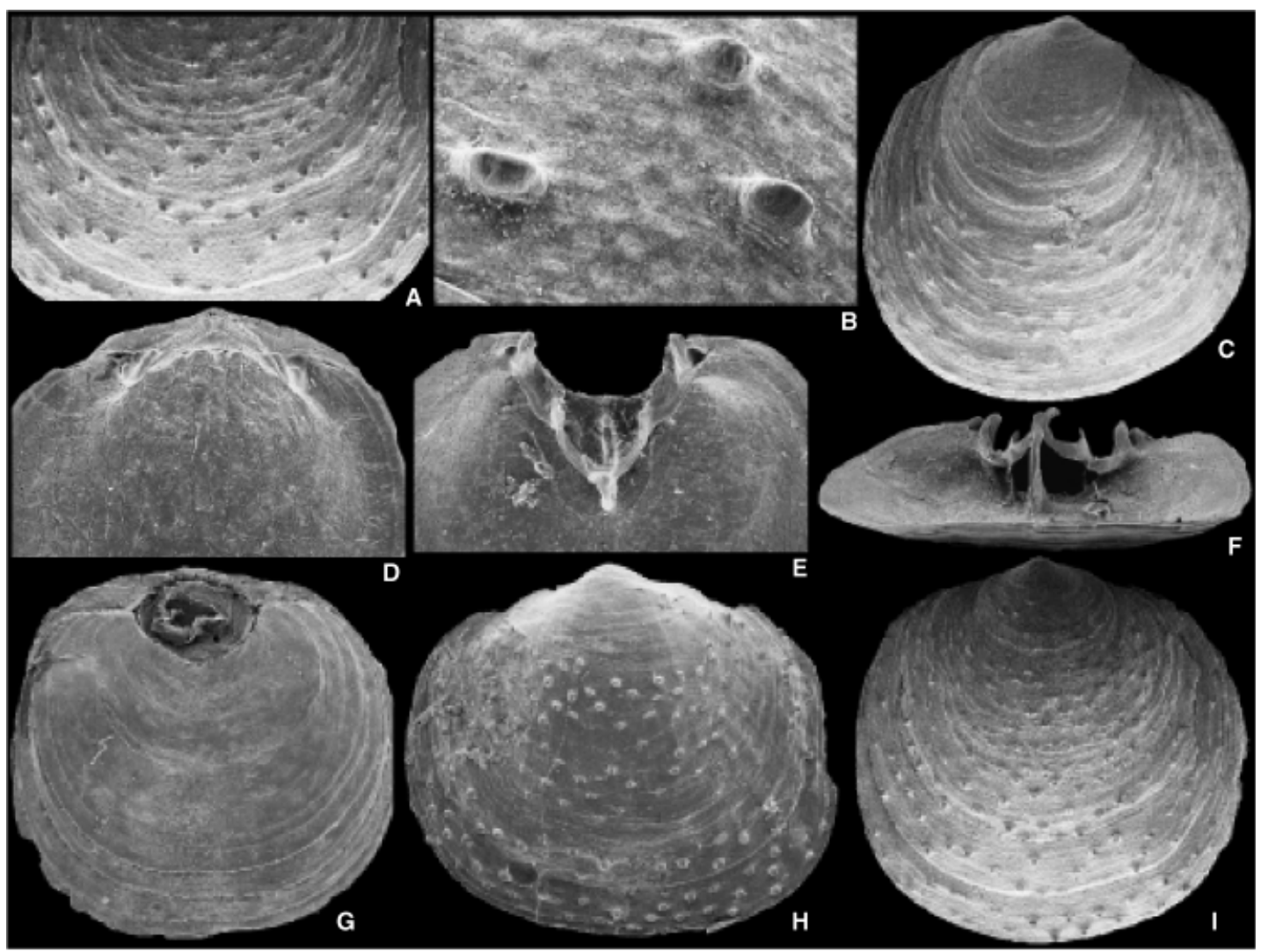

TEXT-FIG. 6. Platidia anomioides. A, dorsal valve exterior, showing details of spinules; DZP-16290, $\times 15 \cdot 5$. B, detail of external surface of specimen $1 ; \times 77$. C, ventral view, specimen DZP-16291; $\times 15 \cdot 8$. D, dorsal valve interior; DZP$16293 ; \times 15$. E-F, the same specimen as D, showing the interior of the dorsal valve with a median septum with two small 'prong-like' ascending branches at its ventral extremity. G, dorsal view of specimen DZP-16288, showing a broad, amphithyrid foramen; $\times 11 \cdot 8$. H-I, ventral views, showing the variation in shell shape. H, specimen showing the presence of spinules; DZP-16289; × 13.1. I, specimen DZP-16290; $\times 11 \cdot 8$. All illustrated specimens from Station 6665, REVIZEE Cruise on January 1, 1998.

Description. Small (maximum length $4 \mathrm{~mm}$, maximum width $5 \mathrm{~mm}$, maximum hinge width $2.6 \mathrm{~mm}$ ), thin, essentially transparent, planoconvex shell. Hinge line nearly straight; anterior comissure rectimarginate. Large amphithyrid foramen about one-third as wide as valve. Beak extremely short, low, inclined. Outline variable, normally subcircular. Shell surface smooth; punctae fine and dense, about 246-285 per $\mathrm{mm}^{2}$.

Ventral valve exterior smooth or with irregularly distributed spinules. Ventral valve interior with minute teeth well below the hinge line.

Dorsal valve interior with high median septum with two 'prong-like' ascending branches at its ventral extremity (Text-fig. 6E-F). Dorsal valve exterior with very fine growth lines; density of puncta in the middle part of the shell ranges from 246 to 285 per $\mathrm{mm}^{2}$.

Discussion. In a preliminary analysis, Simões and Kowalewski (2000) and Simões et al. (2000) assigned the specimens in the collection examined to Amphithyris. Because the outline of the shells of both genera is extremely variable, it is very difficult to separate these platidiid brachiopods on the basis of their shape alone. In fact, as observed by Foster (1974) and Campbell and Fleming (1981), during their life, the dorsal valve of platidiids lies very close to the substrate and becomes moulded to the shape of the bottom surface. Thus, the shell shape is very variable (Text-fig. 6C, G-I) and must be used with caution (if at all) as a 
TABLE 1. Density of punctae in different species of platidiids.

\begin{tabular}{llcl}
\hline Region & Species & Density of puncta & Author \\
\hline Caribbean Sea & Platidia anomioides & $200-275 / \mathrm{mm}^{2}$ & Cooper (1977) \\
North Island of New Zealand & P. anomioides (=P. marionensis) & $481-490 / \mathrm{mm}^{2}$ & Foster (1989) \\
southern Indian Ocean & P. marionensis & $300 / \mathrm{mm}^{2}$ & Cooper (1981) \\
southern Brazilian Shelf & P. anomioides & $246-285 / \mathrm{mm}^{2}$ & This study \\
Antarctic and Subantarctic & Amphithyris buckmani & $>300 / \mathrm{mm}^{2}$ & Foster (1974) \\
Antarctic and Subantarctic & A. hallettensis & $<250 / \mathrm{mm}^{2}$ & Foster (1974) \\
western African coast & A. cf. A. richardsonae & $300 / \mathrm{mm}^{2}$ & Hiller (1994)
\end{tabular}

diagnostic taxonomic feature. According to Foster (1974, p. 84), 'Platidia is essentially identical to Amphithyris in its early stages but soon develops crura, descending branches, ascending branches, and a three-lobed lophophore, which are not seen in Amphithyris specimens of the same size'. The main morphological difference between Platidia and Amphithyris is the presence of a high median septum with two small 'prong-like' ascending branches at its ventral extremity (Foster 1974). The interior of the dorsal valve of the specimens examined (Text-fig. 6E-F) is characterized by the occurrence of a high median septum similar to that illustrated by Muir-Wood et al. (1965) and Foster (1989) for Platidia anomioides. In general, the morphology of the Brazilian specimens agrees well with the descriptions and illustrations of $P$. anomioides given by Foster (1989). The presence of spinules on the exterior side of the ventral valve also makes the specimens studied similar to $P$. anomioides. Although, the species examined is similar in shape to Amphithyris buckmani figured by Campbell and Fleming (1981), the median septum is absent in the latter. Also, Amphithyris cf. A. richardsonae described by (Hiller 1994) is externally similar to our specimens of $P$. anomioides. However, the lophophore of Amphithyris cf. A. richardsonae is of the Amphithyris-type and there is no evidence for presence of crura or branches of a loop (Hiller 1994). Table 1 shows the variation in the density of puncta in different species of Platidia and Amphithyris. As noted by Foster (1989), the density may vary significantly in different populations of Platidia (Table 1). In fact, the range of density observed in the Brazilian specimens is similar to that of $P$. anomioides described by Cooper (1977) for the Caribbean material, reinforcing the similarities between the two forms.

Superfamily BOUCHARDIOIDEA Allan, 1940

Family BOUCHARDIIDAE Allan, 1940

Genus BOUCHARDIA Davidson, 1850

Bouchardia rosea (Mawe, 1823)

Text-figure 7

Material. A total of 11,390 specimens (DZP-4,000-15,390) represented primarily by complete articulated shells.

Description. Small (maximum length $21.1 \mathrm{~mm}$, maximum width $14.6 \mathrm{~mm}$ ), smooth, pink, low Mg-calcite punctate shell. A tight linear correlation between shell length and shell width is observed (Text-fig. 8). Shell fabric including a thin primary shell layer, a thick secondary shell layer with a fibrous fabric and no tertiary shell layer. Outline slightly variable, ovate to elongate-oval. Ventral and dorsal valves heavily thickened posteriorly, with straight beaks, and permesothyrid foramen. Hinge with strongly developed teeth and sockets. Cardinal process and inner socket ridges forming a massive hinge platform; crura absent.

Ventral valve interior with low septal ridge. Dorsal valve interior with high median septum with two posteroventrally curved brachidial lamellae, not united distally, forming an incomplete ring (Text-fig. 7D). Dorsal cardinalia showing prominent $\mathrm{V}$-shaped diductor grooves with longitudinal ridges along their margins (Text-fig. 7C). 


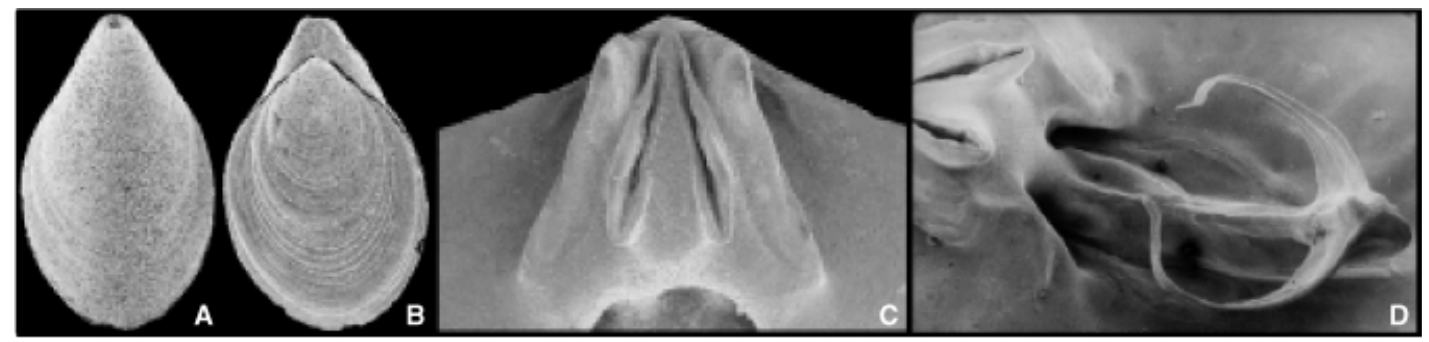

TEXT-FIG. 7. Bouchardia rosea (Mawe). A, ventral valve; DZP-4000; $\times 6 \cdot 5$. B, dorsal valve; DZP-4001; $\times 6 \cdot 0$. C, dorsal valve interior, showing details of the cardinalia; DZP-4002; $\times 12.5$. D, dorsal valve interior, showing the incomplete loop; DZP-4003; ×4 3. Specimens A-C from Station 6653, REVIZEE Cruise on December 15, 1997, and specimen D from Ubatuba bay, São Paulo State.

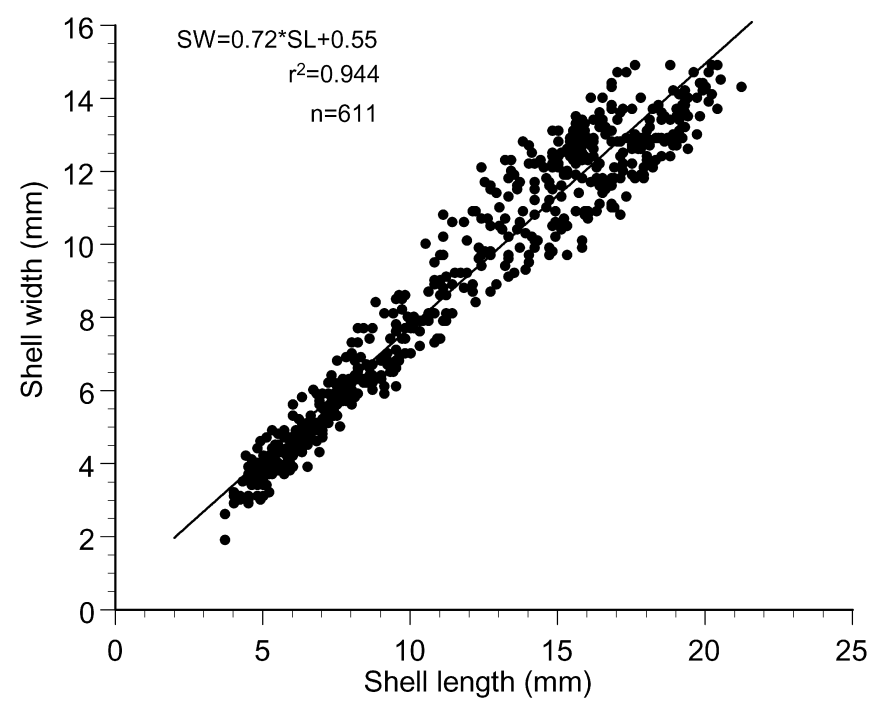

TEXT-FIG. 8. Scatter plot of shell length vs. width for the brachiopod Bouchardia rosea (based on materials from the coastal zone; see Text-fig. 1). SW, shell width; SL, shell length; $\mathrm{r}^{2}$, coefficient of determination (proportion of observed variance explained by the linear correlation between the two variables); n, sample size.

Remarks. Bouchardia rosea (Mawe) is the most common articulated brachiopod in our collection. In recent years, detailed morphological descriptions of B. rosea were given by Brunton (1996) and MacKinnon and Lee (in press) and, thus, only a short description is given here. Valuable information on the musculature of $B$. rosea and other related forms appeared in Minuer and Richardson (1984) and Richardson (1994). The intracrystalline amino acid composition of $B$. rosea shell fabric was recently investigated by Carroll et al. (2001).

In several specimens examined their pedicles are preserved (Text-fig. 3) but show no indication of attachment to substrates (see also Manceñido and Griffin 1988; Brunton 1996). The pedicle in B. rosea is of inert type, suggesting a free mode of live, such as in Anakinetica cumingii (Richardson 1975, 1981b; Mineur and Richardson 1984; Brunton 1996).

B. rosea is restricted to the South Atlantic waters, having a long fossil record ranging back to the Cretaceous (Manceñido and Griffin 1988). Bouchardia was in Antarctica and South America in the Tertiary, but B. rosea is limited to Brazilian waters today (Manceñido and Griffin 1988). However, it should be noted that Jaanusson (1971) mentioned and illustrated one specimen of Bouchardia sp. from 
Singapore. According to Dr Karin Sindemark (Natur Historiska Riksmuseet, Sweden; pers. comm. 2000), this specimen was collected in the Malaysian archipelago by the Eugenie Expedition (1851-53). Unfortunately, the specimen has been lost or destroyed (Sindemark, pers. comm. 2000). Thus, this occurrence cannot be confirmed.

Until now the known geographic distribution of B. rosea was restricted to coastal waters of Bahia (Davidson 1880), Espírito Santo, Rio de Janeiro, and the northern coast of São Paulo State (Tommasi 1970a; Nonato 1999). The discovery of B. rosea populations in waters of Paraná State is the southernmost occurrence of this species and extends notably its latitudinal range southward.

\section{CONCLUDING REMARKS}

The present-day articulated brachiopod fauna from Brazilian waters is more diverse, abundant, and cosmopolitan than previously thought. The fauna includes endemic (B. rosea) and cosmopolitan forms (Argyrotheca cf. cuneata, P. anomioides, and Terebratulina sp.) that are common in the Cenozoic fossil record and occur today in Mediterranean, Caribbean, southern African, and circum-Antarctic waters. The Brazilian fauna differs notably from the adjacent fauna found off the coast of Argentina (Cooper 1973b). Our data parallel those of Foster (1989) and Dawson (1990), showing that the pattern of biogeographic distribution and dispersal history of rhynchonelliform brachiopods is very complex. Owing to the scarcity of data from the Cretaceous-Cenozoic fossil record in the region and the virtual absence of data on modern faunas from the northernmost and southernmost shelves of Brazil, the geographic origin of the Brazilian brachiopod fauna will continue to pose a major challenge for brachiopod researchers.

Acknowledgments. We thank all those people who have provided us with brachiopod specimens for this study, in particular Dr A. Cecilia Z. Amaral (Department of Zoology, UNICAMP) and Dr Adilson Fransozo (Department of Zoology, São Paulo State University). Dr Moyses Gonsalez Tessler (Oceanographic Institute, University of São Paulo) provided valuable sedimentological information for the collecting sites sampled during the REVIZEE project. Comments from Norton Hiller, David A. T. Harper, D. J. Batten and one anonymous reviewer greatly improved the manuscript. We are also indebted to Isaac J. Sayeg who is responsible for the SEM-facility of the Institute of Geosciences, University of São Paulo. This work is a contribution to the REVIZEE-Scour-Sul-Bentos (http:// www.cnpq.br/programas/revizee.htm), and the FAPESP projects 00/12659-7, 99/11431-3.

\section{REFERENCES}

BITNER, M. A. 1990. Middle Miocene (Badenian) brachiopods from the Roztocze Hills, south-eastern Poland. Acta Geologica Polonica, 40, 129-157.

— 1993. Middle Miocene (Badenian) brachiopods from coral reefs of north-western Bulgaria. Acta Geologica Polonica, 43, 147-155.

BLOCHMANN, F. 1908. Zur Systematik und geographischen Verbreitung der Brachiopoden. Zeitschrift für Wissenschaftliche Zoologie, Leipzig, 90, 596-644.

BRUNTON, C. H. C. 1988. Some brachiopods from the eastern Mediterranean Sea. Israel Journal of Zoology, 35, $151-169$.

1996. The functional morphology of the Recent brachiopod Bouchardia rosea. Acta Zoologica, 77, 233-240. and CURRY, G. B. 1979. British brachiopods. Synopses of the British Fauna, 17, 1-464.

BUENING, N. and SPERO, H. J. 1996. Oxygen- and carbon-isotope analyses of the articulate brachiopod Laqueus californianus: a recorder of environmental changes in the subeuphotic zone. Marine Biology, 127, 105-114.

CAMPBELL, H. J. and FLEMING, C. A. 1981. Brachiopoda from Fiordland, New Zealand, collected during the New Golden Hind Expedition, 1946. New Zealand Journal of Zoology, 8, 145-155.

CARROLL, M., KOWALEWSKI, M., SIMÕES, M. G. and GOODFRIEND, G. A. 2001. Amino acid composition and diagenesis in the shells of the terebratulid brachiopod Bouchardia rosea (SW Atlantic). Geological Society of America, Abstracts with Programs, 33, A10.

COOPER, G. A. 1973a. New Brachiopoda from the Indian Ocean. Smithsonian Contributions to Paleobiology, 16, 1-43.

— 1973b. Vema's Brachiopoda (Recent). Smithsonian Contributions to Paleobiology, 17, 1-51.

1977. Brachiopods from the Caribbean Sea, Gulf of Mexico and adjacent waters. Studies of Tropical

Oceanography, 14, 1-211. 
1979. Tertiary and Cretaceous brachiopods from Cuba and the Caribbean. Smithsonian Contributions to Paleobiology, 37, 1-45.

- 1981a. Brachiopods from the southern Indian Ocean (Recent). Smithsonian Contributions to Paleobiology, 43, $1-93$.

1981b. Brachiopods from the Gulf of Gascogne, France (Recent). Smithsonian Contributions to Paleobiology, 44, 1-35.

1982. New brachiopods from the Southern Hemisphere and Cryptopora from Oregon (Recent). Smithsonian Contributions to Paleobiology, 41, 1-43.

COPPER, P. and JIN, J. (eds) 1996. Brachiopods. Proceedings of the Third International Brachiopod Congress. Balkema, Rotterdam, $373 \mathrm{pp}$.

CURRY, G. B. 1982. Ecology and population structure of the Recent brachiopod Terebratulina from Scotland. Palaeontology, 25, 227-246.

- and ENDO, K. 1991. Migration of brachiopod species in the North Atlantic in response to Holocene climatic change. Geology, 19, 1101-1103.

DAVIDSON, T. 1880. Report on the Brachiopoda dredged by H. M. S. Challenger during the years 1873-1876. Report on the Scientific Research of the Voyage of H. M. S. Challenger, Zoology, 1, 1-67.

- 1887. A monograph of Recent Brachiopoda, part 2. Transactions of the Linnean Society of London, Series 2, Zoology, 4, 75-182.

DAWSON, E. W. 1990. The systematics and biogeography of the living Brachiopoda of New Zealand. 431-438. In MACKINNON, D. I., LEE, D. E. and CAMPBELL, J. D. (eds). Brachiopods through time. Balkema, Rotterdam, 447 pp.

DUtRO, J. T., Jr and BOARDMAN, R. S. (eds) 1981. Lophophorates. Paleontological Society Short Course Notes. University of Tenessee Studies in Geology, 5, 1-219.

EICHLER, P. 1911. Die Brachiopoden. Deutsche Südpolar Expedition, 12, 383-401.

ENDO, K., REYMENT, R. A. and CURRY, G. B. 1995. Taxonomic relationships in Terebratulina (Brachiopoda) established by multivariate morphometrics. Revista Española de Paleontología, 10, 109-116.

FISCHER, P. and OEHLERT, D. P. 1892. Résultats de campagnes scientifiques accomplis sur son yacht (l'Hirondelle) par Albert Ier, Prince Souverain de Monaco, 3: Brachiopodes de l'Atlantique Nord. Monaco, 30 pp.

FOSTER, M. W. 1974. Recent Antarctic and Subantarctic brachiopods. Antarctic Research Series, 21, 1-189. 1989. Brachiopods from the extreme South Pacific and adjacent waters. Journal of Paleontology, 63, 268-301.

FÜRSICH, F. T. and HURST, J. M. 1974. Environmental factors determining the distribution of brachiopods. Palaeontology, 17, 879-900.

HATAI, K. 1940. The Cenozoic Brachiopoda of Japan. Tohoku Imperial University, Science Reports, Series 2, $20,1-413$. HILLER, N. 1986. The South African Museum's Meiring Naude Cruises Part 16 - Brachiopoda from the 1975-1979 cruises. Annals of the South African Museum, 97, 97-140.

— 1990. The southern African Recent brachiopod fauna. 439-445. In MACKINNON, D. I., LEE, D. E. and CAMPBELL, J. D. (eds). Brachiopods through time. Balkema, Rotterdam, $447 \mathrm{pp}$.

1994. The environment, biogeography, and origin of the Southern African Recent brachiopod fauna. Journal of Paleontology, 68, 776-786.

JAANUSSON, v. 1971. Evolution of the brachiopod hinge. Smithsonian Contributions to Paleobiology, 3, 33-67.

JAMES, M. A., ANSELL, A. D., COLLINS, M. J., CURRY, G. B., PECK, L. S. and RHODES, M. C. 1992. Biology of living brachiopods.

Advances in Marine Biology, 28, 175-387.

KOWALEWSKI, M. 1996. Taphonomy of a living fossil: the lingulide brachiopod Glottidia palmeri Dall from Baja California, Mexico. Palaios, 11, 244-265.

- SIMÕES, M. G., CARROLL, M. and RODLAND, D. L. 2002. Abundant brachiopods on a tropical, upwelling-influenced shelf (Southeast Brazilian Bight, South Atlantic). Palaios, 17, 274-283.

LAURIN, B. 1997. Brachiopodes récoltés dans les eaux de Nouvelle-Calédonie et des îles Loyauté, Matthew et Chesterfield. 411-471. In CROSNIER, A. (ed.). Résultats des Campagnes Musorstom. Mémoires du Muséum National d'Histoire naturelle, 176, $570 \mathrm{pp}$.

LEE, D. E. 1991. Aspects of the ecology and distribution of the living Brachiopoda of New Zealand. 273-279. In MACKINNON, D. I., LEE, D. E. and CAMPBELL, J. D. (eds). Brachiopods through time. Balkema, Rotterdam, 447 pp.

LOGAN, A. 1979. The recent Brachiopoda of the Mediterranean Sea. Bulletin de l'Institut Océanographique de Monaco, 72, $1-112$.

1983. Brachiopoda collected by CANCAP 1-111 expeditions to the south-east North Atlantic, 1976-1978. Zoologische Mededelingen, 57, 165-189.

MACKINNON, D. I. and LEE, D. E. in press. Superfamily Bouchardioidea Allan, 1940. In KAESLER, R. L. (ed.). Treatise on invertebrate paleontology, Part H, Brachiopoda (revised). Geological Society of America, Boulder, and University of Kansas Press, Lawrence. 
— LEE, D. E. and CAMPBELL, J. D. 1990. Brachiopoda through time. Balkema, Rotterdam, 447 pp.

MANCENIIDO, M. O. and GRIFFIN, M. 1988. Distribution and palaeoenvironmental significance of the genus Bouchardia (Brachiopoda, Terebratellidina): its bearing on the Cenozoic evolution of the South Atlantic. Revista Brasileira de Geociências, 18, 201-211.

MINEUR, R. J. and RICHARDSON, J. R. 1984. Free and mobile brachiopods from the New Zealand Oligocene deposits and Australian waters. Alcheringa, 10, 327-334.

MUIR-WOOD, H. M. 1959. Report on the Brachiopoda of the John Murray Expedition. John Murray Expedition 1933-1934, Scientific Reports, (6), 10, 283-317.

— ElliotT, G. F. and HAtAi, K. 1965. Mesozoic and Cenozoic Terebratellidina. H816-H857. In MOORE, R. C. (ed.). Treatise on invertebrate paleontology, Part H, Brachiopoda 2. Geological Society of America, Boulder, and University of Kansas Press, Lawrence, 404 pp. (H523-H927).

NONATO, E. F. 1999. Filo Brachiopoda. 255-257. In MigOTTO, A. E. and TIAGO, C. G. (eds). Biodiversidade do estado de São Paulo, Brasil: síntese do conhecimento ao final do século XX. Invertebrados Marinhos, 3, FAPESP, São Paulo, $310 \mathrm{pp}$.

— and PETTI, M. A. V. 1996. Macrofauna bentônica das enseadas de Picinguaba e Ubatumirim: ocorrência de espécies raras e descrição de novas espécies. Resumos do III Simpósio sobre Oceanografia. Instituto Oceanográfico, Universidade de São Paulo, São Paulo, p. 219.

PALACIO, F. J. 1982. Revisión zoogeográfica marina del sur del Brasil. Boletim do Instituto Oceanográfico, São Paulo, 31, 69-92.

PECK, L. S. 2001. Ecology of articulated brachiopods. 171-184. In CARLSON, S. J. and SANDY, M. R. (eds). Brachiopods ancient and modern. Paleontological Society, Special Papers, 7, $261 \mathrm{pp}$.

PENNINGTON, J. T., TAMBURRI, M. N. and BARRY, J. P. 1999. Development, temperature tolerance, and settlement preference of embryos and larvae of the articulate brachiopod Laqueus californianus. Biological Bulletin, 196, $245-256$.

POPIEL-BARCZYK, E. and BARCZYK, W. 1987. Eocene brachiopods from Wola Luzanska and Skalnik in the Central Carpathians. Acta Geologica Polonica, 37, 93-103.

1990. Middle Miocene (Badenian) brachiopods from the southern slopes of the Holy Cross Mountains,

Central Poland. Acta Geologica Polonica, 40, 159-181.

RICHARDSON, J. R. 1975. Locomotory adaptations in a free-lying brachiopod. Science, 189, 381-382.

— 1981a. Recent brachiopods from New Zealand. New Zealand Journal of Zoology, 8, 133-248.

$1981 b$. Brachiopods and pedicles. Paleobiology, 7, 87-95.

1987. Brachiopods from carbonate sands of the Australian Shelf. Proceedings of the Royal Society of Victoria,

99, 37-50.

1994. Origins and dispersal of a brachiopod family - the systematics, biogeography and evolution of the Family

Terebratellidae. Proceedings of the Royal Society of Victoria, 106, 17-29.

— 1997a. Biogeography of articulated brachiopods. 463-472. In KAESLER, R. L. et al. (ed.). Treatise on invertebrate paleontology, Part H, Brachiopoda 1 (revised). Geological Society of America, Boulder, and University of Kansas Press, Lawrence, 539 pp.

— 1997b. Ecology of articulated brachiopods. 441-462. In KAESLER, R. L. et al. (ed.). Treatise on invertebrate paleontology, Part H, Brachiopoda 1 (revised). Geological Society of America, Boulder, and University of Kansas Press, Lawrence, 539 pp.

ROUX, A. and BREMEC, C. 1996. Brachiopoda collected in the western South Atlantic by R/V Shinkai Maru Cruises (1978-1979). Revista Investigación y Desarrollo Pesquero, 10, 109-114.

RUDWICK, M. J. S. 1970. Living and fossil brachiopods. Hutchinson, London, 199 pp.

SAVAZZI, E. 1999. Functional morphology of the invertebrate skeleton. Wiley, London, $687 \mathrm{pp}$.

SIMÕES, M. G. and KOWALEWSKI, M. 2000. Recent brachiopods from the Brazilian continental shelf (South Atlantic): a preliminary report. Abstracts of the Millenium Brachiopod Congress, London, p. 80.

- KOWALEWSKI, M., MELlO, L. H. C., RODLAND, D. L. and CARROL, M. 2000. Present-day terebratulid brachiopods from the southern Brazilian shelf: paleontological and biogeographic implications. Geological Society of America, Abstracts with Programs, 32, A14.

THAYER, C. W. 1977. Recruitment, growth, and mortality of a living articulate brachiopod, with implications for the interpretation of survivorship curves. Paleobiology, 3, 98-109.

TOMMASI, L. R. 1967. Observações preliminares sobre a fauna bêntica de sedimentos moles da Baía de Santos e regiões vizinhas. Boletim do Instituto Oceanográfico, 16, 43-65.

1970a. Sobre o braquiópode Bouchardia rosea (Mawe), 1823. Boletim do Instituto Oceanográfico, 19, $33-42$.

— 1970b. Observações sobre a fauna bêntica do complexo estuarino-lagunar de Cananéia. Boletim do Instituto Oceanográfico, 19, 43-56. 
TUNNICLIFFE, V. and WILSON, K. 1988. Brachiopod populations: distribution in fjords of British Columbia (Canada) and tolerance of low oxygen concentration. Marine Ecology Progress Series, 47, 117-128.

WILLIAMS, A., CARLSON, S. J., BRUNTON, C. H. C., HOLMER, L. E. and POPOV, L. E. 1996. A supra-ordinal classification of the Brachiopoda. Philosophical Transactions of the Royal Society, London B, 351, 1171-1193.

WILliams, A., ROWELl, A. J., MUIR-WOOD, H. M., PITRAT, C. W. et al. 1965. Brachiopoda. In MOORE, R. C. (ed.). Treatise on Invertebrate Paleontology, Part $H$, volume 1. Geological Society of America, Boulder, and University of Kansas Press, Lawrence, $521 \mathrm{pp}$.

Williams, A., BRUNTON, C. H. C., CARLSON, S. J., ALVAREZ, F. et al. 1997. Brachiopoda. In KAESLER, R. L. (ed.). Treatise on Invertebrate Paleontology, Part H, volume 1. (revised). Geological Society of America, Boulder, and University of Kansas Press, Lawrence, 539 pp.

ZEZINA, O.N. 1981a. Recent Deep-Sea Brachiopoda from the Western Pacific. Galathea Report, 15, 7-20. 1981b. New and rare cancellothyroid brachiopods in the bathyal and abyssal ocean. Trudy Instituta Okeanologii, Akademia Nauk SSSR, 115, 55-164.

1987. Brachiopods collected by Benthedi-Cruise in the Mozambique Channel. Bulletin du Muséum Nationale d'Histoire Naturelle, Paris, Serie 4, 9, 551-563.

Typescript received 28 March 2002

Revised typescript received 15 January 2003
MARCELLO G. SIMÕES

Instituto de Biociências, Universidade Estadual Paulista Campus de Botucatu, Rubião Junior

Botucatu, CP 510

CEP 18.618-000, São Paulo, Brazil e-mail btsimoes@ibb.unesp.br

MICHAŁ KOWALEWSKI

DAVID L. RODLAND ${ }^{1}$

MONICA CARROLL ${ }^{2}$

Department of Geological Sciences

Virginia Polytechnic Institute and State University

Blacksburg, Virginia 24061, USA

1 and

Department of Earth Sciences Morrill Hall

Southern Connecticut State University 501 Crescent St

New Haven, Connecticut 06515, USA

2 and

Department of Geology

University of Georgia

Athens, Georgia 30602, USA

LUIZ H. C. MELLO

Instituto de Biociências, Universidade Estadual Paulista

Campus de Botucatu, Rubião Junior

Botucatu, CP 510

CEP 18.618-000, São Paulo, Brazil and

Programa de Pós-graduação em Geologia Sedimentar Instituto de Geociências

Universidade de São Paulo, CP 11.348

CEP 05508-900, São Paulo, Brazil 


\section{APPENDIX}

Brachiopod collection data for the REVIZEE Oceanographic Project

\begin{tabular}{|c|c|c|c|c|c|}
\hline Station & Species & $\begin{array}{l}\text { Number of } \\
\text { specimens }\end{array}$ & $\begin{array}{l}\text { Latitude } \\
\text { Longitude }\end{array}$ & Depth & Cruise date \\
\hline 6644 & B. rosea & 1 & $\begin{array}{l}25.45 .80 \\
45.11 .77\end{array}$ & 485 & December 14, 1997 \\
\hline \multirow[t]{2}{*}{6646} & Terebratulina $\mathrm{sp}$. & 1 & $\begin{array}{l}25.43 .78 \\
45.16 .06\end{array}$ & 198 & December 14, 1997 \\
\hline & $\begin{array}{l}\text { Argyrotheca cf. cuneata } \\
\text { B. rosea }\end{array}$ & $\begin{array}{r}1 \\
69\end{array}$ & & & \\
\hline \multirow[t]{2}{*}{6650} & Terebratulina sp. & 3 & $\begin{array}{l}25.57 .39 \\
45.34 .25\end{array}$ & 417 & December 15, 1997 \\
\hline & B. rosea & 1 & & & \\
\hline 6651 & B. rosea & 1 & $\begin{array}{l}25.53 .58 \\
45.42 .13\end{array}$ & 256 & December 15, 1997 \\
\hline 6652 & B. rosea & 1 & $\begin{array}{l}25.51 .04 \\
45.47 .30\end{array}$ & 206 & December 15, 1997 \\
\hline 6653 & B. rosea & 8,809 & $\begin{array}{l}25.43 .50 \\
46.02 .50\end{array}$ & 155 & December 15, 1997 \\
\hline 6661 & Terebratulina sp. & 2 & $\begin{array}{l}24.07 .637 \\
45.51 .895\end{array}$ & 147 & January 9, 1998 \\
\hline 6665 & $\begin{array}{l}\text { Argyrotheca } \text { cf. cuneata } \\
\text { P. anomioides } \\
\text { B. rosea } \\
\text { Terebratulina sp. }\end{array}$ & $\begin{array}{r}17 \\
440 \\
2 \\
99\end{array}$ & $\begin{array}{l}24.20 .844 \\
44.09 .913\end{array}$ & 258 & January 10, 1998 \\
\hline 6666 & $\begin{array}{l}\text { Argyrotheca cf. cuneata } \\
\text { P. anomioides } \\
\text { Terebratulina sp. }\end{array}$ & $\begin{array}{r}51 \\
4 \\
47\end{array}$ & $\begin{array}{l}24.17 .129 \\
44.12 .179\end{array}$ & 163 & January 10, 1998 \\
\hline 6669 & B. rosea & 1 & $\begin{array}{l}24.07 .347 \\
44.42 .142\end{array}$ & 101 & January 11, 1998 \\
\hline 6672 & $\begin{array}{l}\text { Terebratulina sp. } \\
\text { Argyrotheca } \text { cf. cuneata } \\
\text { B. rosea } \\
\text { P. anomioides }\end{array}$ & $\begin{array}{r}33 \\
34 \\
1 \\
1\end{array}$ & $\begin{array}{l}26.27 .75 \\
44.30 .351\end{array}$ & 165 & January 11, 1998 \\
\hline 6673 & $\begin{array}{l}\text { Terebratulina sp. } \\
\text { Argyrotheca cf. cuneata } \\
\text { B. rosea }\end{array}$ & $\begin{array}{l}54 \\
46 \\
20\end{array}$ & $\begin{array}{l}24.17 .939 \\
44.35 .983\end{array}$ & 133 & January 11, 1998 \\
\hline 6674 & $\begin{array}{l}\text { Terebratulina sp. } \\
\text { B. rosea }\end{array}$ & $\begin{array}{r}3 \\
103\end{array}$ & $\begin{array}{l}24.31 .08 \\
44.54 .00\end{array}$ & 122 & January 11, 1998 \\
\hline 6676 & $\begin{array}{l}\text { Terebratulina sp. } \\
\text { Argyrotheca } \text { cf. cuneata }\end{array}$ & $\begin{array}{l}167 \\
167\end{array}$ & $\begin{array}{l}24.49 .699 \\
44.44 .965\end{array}$ & 153 & January 12, 1998 \\
\hline 6677 & Terebratulina sp. & 52 & $\begin{array}{l}24.40 .747 \\
44.50 .822\end{array}$ & 137 & January 12, 1998 \\
\hline \multirow[t]{2}{*}{6678} & $\begin{array}{l}\text { Argyrotheca } \mathrm{cf} \text {. cuneata } \\
\text { Terebratulina } \mathrm{sp} .\end{array}$ & $\begin{array}{r}65 \\
3\end{array}$ & $\begin{array}{l}24.46 .357 \\
45.11 .135\end{array}$ & 99 & January 12, 1998 \\
\hline & $\begin{array}{l}\text { Argyrotheca cf. cuneata } \\
\text { B. rosea }\end{array}$ & $\begin{array}{r}10 \\
9\end{array}$ & & & \\
\hline
\end{tabular}


SIMÕES ET AL.: PALAEONTOLOGICAL IMPLICATIONS OF RECENT BRACHIOPODS

\begin{tabular}{|c|c|c|c|c|c|}
\hline Station & Species & $\begin{array}{l}\text { Number of } \\
\text { specimens }\end{array}$ & $\begin{array}{l}\text { Latitude } \\
\text { Longitude }\end{array}$ & Depth & Cruise date \\
\hline \multirow[t]{2}{*}{6681} & Terebratulina sp. & 11 & $\begin{array}{l}25.11 .005 \\
44.56 .6\end{array}$ & 168 & January 12,1998 \\
\hline & Argyrotheca $\mathrm{cf}$. cuneata & 10 & & & \\
\hline 6685 & Terebratulina sp. & 2 & $\begin{array}{l}25.41 .827 \\
45.11 .686\end{array}$ & 282 & January 13,1998 \\
\hline \multirow[t]{4}{*}{6686} & Terebratulina sp. & 5 & $\begin{array}{l}25.36 .988 \\
45.13 .571\end{array}$ & $?$ & January 13,1998 \\
\hline & Argyrotheca $\mathrm{cf}$. cuneata & 8 & & & \\
\hline & P. anomioides & 1 & & & \\
\hline & B. rosea & 1 & & & \\
\hline 6695 & B. rosea & 17 & $\begin{array}{l}26.17 .51 \\
46.41 .23\end{array}$ & 153 & January 19, 1998 \\
\hline 6698 & B. rosea & 57 & $\begin{array}{l}26.10 .87 \\
46.20 .01\end{array}$ & 241 & January 20, 1998 \\
\hline \multirow[t]{2}{*}{6699} & Terebratulina sp. & 2 & $\begin{array}{l}26.01 .26 \\
46.25 .26\end{array}$ & 150 & January 20, 1998 \\
\hline & B. rosea & 1,269 & & & \\
\hline 6703 & B. rosea & 609 & $\begin{array}{l}25.39 .70 \\
46.13 .20\end{array}$ & 133 & January 21, 1998 \\
\hline 6704 & B. rosea & 1 & $\begin{array}{l}25.14 .60 \\
46.03 .00\end{array}$ & 100 & January 21, 1998 \\
\hline \multirow[t]{2}{*}{6706} & B. rosea & 137 & $\begin{array}{l}25.48 .60 \\
45.44 .50\end{array}$ & 184 & January 21, 1998 \\
\hline & Terebratulina sp. & 1 & & & \\
\hline 6777 & Terebratulina sp. & 1 & $\begin{array}{l}26.51 .76 \\
46.18 .37\end{array}$ & 500 & March 13, 1998 \\
\hline 6787 & B. rosea & 5 & $\begin{array}{l}27.27 .83 \\
47.24 .22\end{array}$ & 151 & March 15, 1998 \\
\hline 6793 & B. rosea & 50 & $\begin{array}{l}27.46 .49 \\
47.40 .45\end{array}$ & 138 & March 16, 1998 \\
\hline 6808 & B. rosea & 226 & $\begin{array}{l}28.48 .67 \\
48.00 .19\end{array}$ & 141 & March 22, 1998 \\
\hline
\end{tabular}

